\title{
Synthesis of Ceria Zirconia Oxides using Solvothermal Treatment
}

\author{
Siti Machmudah ${ }^{1,{ }^{*}}$, Widiyastuti ${ }^{1}$, Sugeng Winardi ${ }^{1}$, Wahyudiono ${ }^{2}$, Hideki Kanda $^{2}$, and Motonobu Goto ${ }^{2}$ \\ ${ }^{1}$ Department of Chemical Engineering, Institut Teknologi Sepuluh Nopember, Surabaya 60111, Indonesia \\ ${ }^{2}$ Department of Materials Process Engineering, Nagoya University, Furo-cho, Chikusa-ku, Nagoya 464-8603, Japan
}

\begin{abstract}
Ceria oxide $\left(\mathrm{CeO}_{2}\right)$ is widely used as catalyst with high oxygen storage capacity at low temperature. The addition of zirconia oxide $\left(\mathrm{ZrO}_{2}\right)$ to $\mathrm{CeO}_{2}$ can enhance oxygen storage capacity as well as thermal stability. In this work, ceria zirconia oxides has been synthesized via a low temperature solvothermal treatment in order to produce ceria zirconia oxides composite with high oxygen storage capacity as electrolyte of solid oxide fuel cells (SOFC). Under solvothermal conditions, solvent may control the direction of crystal growth, morphology, particle size and size distribution, because of the controllability of thermodynamics and transport properties by pressure and temperature. Water, mixed of water and ethanol $(70 / 30 \mathrm{vol} / \mathrm{vol})$, and mixed of water and ethylene glycol $(70 / 30 \mathrm{vol} / \mathrm{vol})$ were used as solvent, while $\mathrm{Ce}\left(\mathrm{NO}_{3}\right)_{3}$ and $\mathrm{ZrO}\left(\mathrm{NO}_{3}\right)_{2}$ with $0.06 \mathrm{M}$ concentration were used as precursor. The experiments were conducted at temperature of $150{ }^{\circ} \mathrm{C}$ and pressure for $2 \mathrm{~h}$ in a Teflon-lined autoclave of $100 \mathrm{~mL}$ volume. The synthesized products were dried at $60^{\circ} \mathrm{C}$ for 6 and $12 \mathrm{~h}$ and then calcined at $900{ }^{\circ} \mathrm{C}$ for $6 \mathrm{~h}$. The particle products were characterized using SEM, XRD, TG/DTA, and Potentiostat. The results showed that the morphology of particles formed were affected by the solvent. Solid plate shaped particles were produced in water, and tend to be pore with the addition of ethylene glycol. The addition of ethanol decreased the size of particles with sphere shaped. The XRD pattern indicated that ceria-zirconia oxides particles are uniformly distributed in the structure to form a homogeneous solid solution. Based on the electrochemical analysis, ceria zirconia oxides produced via solvothermal synthesis had high conductivity ion of $0.5594 \mathrm{~S} / \mathrm{cm}$, which is higher than minimum conductivity ion requirement of $0.01 \mathrm{~S} / \mathrm{cm}$ for SOFC electrolyte. It indicated that ceria zirconia oxides produced via solvothermal synthesis is suitable for SOFC electrolyte.
\end{abstract}

\section{Introduction}

The central part of a Solid Oxide Fuel Cell (SOFC) is electrolyte, which is sandwiched between cathode and anode. The oxygen ions $\left(\mathrm{O}^{2-}\right)$ reduced on cathode or proton $\left(\mathrm{H}^{+}\right)$oxidized on anode sides is transported through the electrolyte materials and reacts with hydrogen or oxygen, respectively, to form water on either side of the cell. The electrons $\left(\mathrm{e}^{-}\right)$are generated due to the reaction pass in the opposite direction through the outer circuit [1]. There are two types of materials: oxide ion and proton conducting electrolytes. Oxide ion conducting electrolytes cover a wide range of materials which basically include fluorite-, perovskite-, brownmillerite-structured materials. Fluorite-structured electrolyte is adopted by ceria at room temperature and zirconia at high temperature. Basically zirconia and ceria based materials are widely investigated for its application as electrolyte in solid oxide fuel cell (SOFC) [2].
To increase performance of SOFC, electrolyte should be able to store and transport oxygen in large quantities to be reacted with hydrogen. In this case, oxygen storage/release capacity (OSC) is an important feature for electrolyte fabrication. Ceria has high OSC based on the reversible redox reaction $\left(\mathrm{CeO}_{2} \leftrightarrow \mathrm{CeO}_{2-\mathrm{x}}+\mathrm{x} / 2 \mathrm{O}_{2}\right.$; $\mathrm{x}=0-0.5$ ) [3]. However, the OSC performance and durability of pure $\mathrm{CeO}_{2}$ are still inadequate for its use at high temperature. Furthermore, it is necessary to mix it with ceramic material that has stability at high temperature. Zirconia oxide $\left(\mathrm{ZrO}_{2}\right)$ is a polymorphic oxide that is stable at high temperature [4] and exists in three different crystal structures: (i) cubic from $2367{ }^{\circ} \mathrm{C}$ up to its melting point of $2677^{\circ} \mathrm{C}$, (ii) tetragonal from $1167^{\circ} \mathrm{C}$ up to $2367^{\circ} \mathrm{C}$ and (iii) monoclinic below 1167 ${ }^{\circ} \mathrm{C}[5]$.

Nagai et al. [3] has prepared $\mathrm{CeO}_{2}-\mathrm{ZrO}_{2}$ mixed oxides by precipitation method. This method is simple, but the morphology and size of particles are difficult to be controlled. Synthesis of $8 \mathrm{~mol} \%$ yttria-stabilized zirconia doped with $10 \mathrm{~mol} \%$ ceria has also been

Corresponding author: machmudah@chem-eng.its.ac.id 
conducted by Bekale et al. [6] via wet chemical process. This process is expensive, takes long time and needs various chemicals to be used. Solvothermal method is one of the simple methods for synthesis of ceria zirconia oxides particles. Similar to the hydrothermal method, in solvothermal method particles are formed in an organic solvent or water at temperature above boiling point of solvent and pressure above vapour pressure of solvent. Solvothermal process has many advantages in addition to being a green process: (1) it is energy efficient because of low temperature synthesis, (2) it is an environmentally friendly process because of closed system conditions, (3) unused components can be recycled, (4) precipitants are not always needed, (5) high-purity products can be synthesized, (6) metastable and new phases can be accessed, and (7) crystal size, morphology, composition, and polymorphism of the synthesized phases are easily controlled $[7,8]$.

This work is focused on the synthesis of ceria zirconia oxides using solvothermal method at various solvent compositions. The solvent used was water, ethanol, and ethylene glycol with various compositions. The morphology, oxygen storage capacity, and electrical property of particles were also investigated.

\section{Experimental Method}

\subsection{Synthesis of ceria zirconia oxides particles}

Ceria zirconia oxides particles were prepared by a solvothermal process in a batch reactor. All chemicals were of analytical grade and used without further purification. $\mathrm{Ce}\left(\mathrm{NO}_{3}\right)_{3} \cdot 6 \mathrm{H}_{2} \mathrm{O}$ (Sigma Aldrich, Germany) and $\mathrm{ZrO}\left(\mathrm{NO}_{3}\right)_{2}$ (Wako, Japan) were used as precursor. Water, mixed of water and ethanol (70/30 and 50/50 $\mathrm{vol} / \mathrm{vol})$, and mixed of water and ethylene glycol (70/30 $\mathrm{vol} / \mathrm{vol}$ ) were used as solvent. Firstly, solution of $0.06 \mathrm{M}$ cerium nitrate and zirconium oxynitrate were prepared separately in the solvent, and mixed with ratio of $1: 1$ ( $\mathrm{vol} / \mathrm{vol})$. Then, the certain volume of solution was moved into a Teflon-lined autoclave of $100 \mathrm{~mL}$ volume. The autoclave reactor was placed into an electric furnace (Linn High Therm GmbH, model VMK 1600, Germany) and quickly heated to $150^{\circ} \mathrm{C}$. The temperature in the reactor was measured by a thermocouple (K-type) inserted in the reactor cover. The time required to heat the reactor from room temperature to $150^{\circ} \mathrm{C}$ was around $10 \mathrm{~min}$ and thereafter the reactor temperature was constant. The difference between the furnace temperature and the reactor temperature was approximately $7^{\circ} \mathrm{C}$. The pressure was autogenously generated when the reactor was sealed and heated. After $2 \mathrm{~h}$ (including the heating time of about $10 \mathrm{~min}$ ), the reactor was removed from the electric furnace and quickly quenched in a water bath at room temperature. After cooling, the reactor was opened and the resultant precipitate was filtered and washed repeatedly with deionized water. The obtained particles were dried at $60^{\circ} \mathrm{C}$ for 6 and $12 \mathrm{~h}$ and then calcined at $900^{\circ} \mathrm{C}$ for $6 \mathrm{~h}$.

\subsection{Characterization of particles}

The morphologies of the calcined particles were observed using SEM (JEOL JSM-6390LV). It is well known that SEM has the capability to detect particle diameters and morphologies, but the resolution is lost at extreme magnifications. In addition, SEM requires the samples to be electrically conductive, therefore, for most of the particles produced, a gold or platinum coating must be applied that may alter the diameter readings at higher magnifications. XRD patterns were determined to confirm that the crystal structure of ceria-zirconia oxides was formed via this synthesis method. A Rigaku RINT 2100/PC XRD machine ( $40 \mathrm{kV}$ and $200 \mathrm{~mA}$ ) equipped with a $\mathrm{h}-\mathrm{h}$ wide-angle goniometer and scintillation detector was used for all XRD measurements, using $\mathrm{Cu}$ Ka radiation $\left(\mathrm{k}=1.5406 \mathrm{~A}^{\circ}\right)$. The composition of ceria zirconia oxides particles was analyzed using Energy Dispersive X-ray spectroscopy (EDX). The oxygen storage capacity (OSC) was determined by thermogravimetric analysis [3]. Initially, ceria zirconia oxides samples loaded on the platinum plate were fed with $\mathrm{N}_{2}$ and heated from room temperature to $600^{\circ} \mathrm{C}$ at temperature rate $50^{\circ} \mathrm{C} / \mathrm{min}$ to release free oxygen in the sample, then the temperature was reduced. The samples were oxydized with $\mathrm{O}_{2}$ and and heated from room temperature to $600^{\circ} \mathrm{C}$ at temperature rate $50^{\circ} \mathrm{C} / \mathrm{min}$ to determine oxygen storage and stability of samples at high temperature. The weight loss and gain were measure using a thermo-gravimetric analysis (TGA-50, Shimadzu, Japan). The value of the weight change between the releasing and oxydizing corresponds to total OSC. To determine electrical performance of particles product, the impedance spectra was measured by Potentiostat VersaStat 4.

\section{Result and Discussion}

Morphology of ceria zirconia oxides particles produced at various solvents at drying times is shown in Figure 1. Ceria zirconia oxides was produced using water, mixed water/ethanol $(70 / 30$ and $50 / 50(\mathrm{v} / \mathrm{v}))$, and mixed water/ethylene glycol $(70 / 30(\mathrm{v} / \mathrm{v}))$ as solvent at $150^{\circ} \mathrm{C}$ for $2 \mathrm{~h}$ with drying times of 6 and $12 \mathrm{~h}$. In general, particles were composed of small sphere particles agglomerated into plate like shape. Particles produced using water as solvent were agglomerated into solid plate like shape with smooth surface and big size. By addition ethanol into the solvent, the agglomerated particles size became smaller and tend to be spherical shape. Moreover, by addition ethylene glycol into the solvent, the spherical particles formed agglomerated particles with large amount of pore. These results indicated that morphology particles were highly influenced by the type of solvent. It can be explained that every solvent has a specific dielectric constant that influences reaction occurred during the solvothermal synthesis. Moreover, the addition of chemicals into the water in high temperature particles synthesis could control the size and shape of particles formed [9]. 


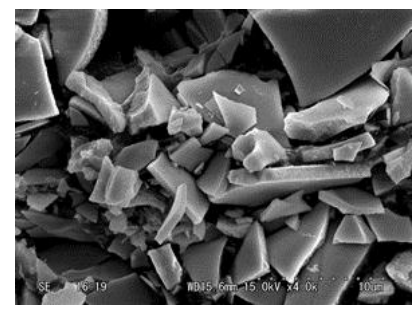

(a)

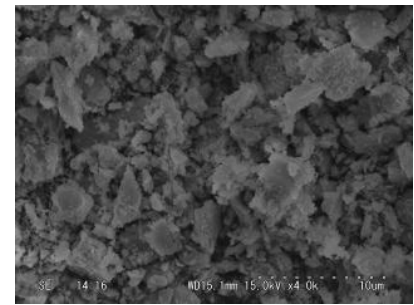

(c)

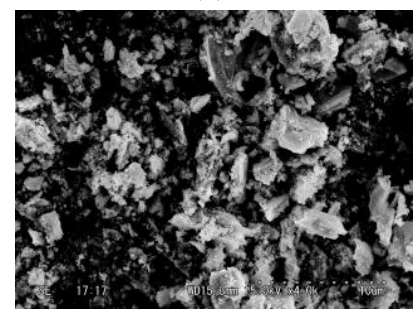

(e)

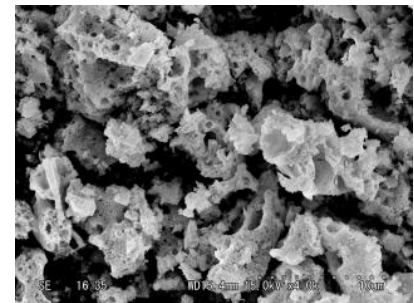

(g)

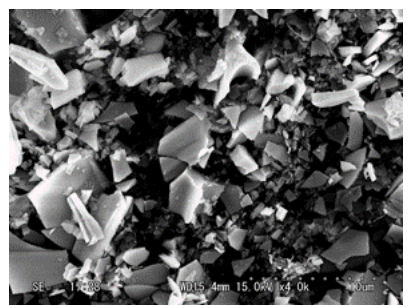

(b)

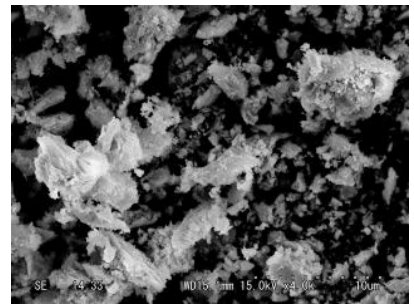

(d)

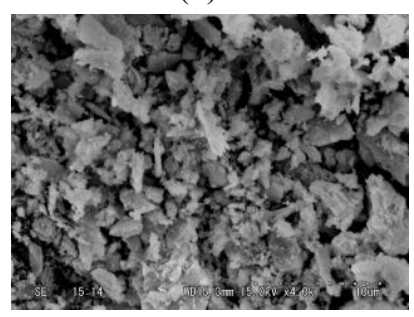

(f)

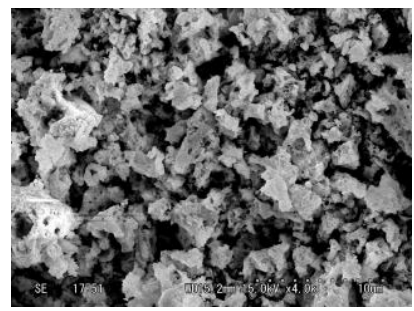

(h)
Fig. 1. SEM images of ceria zirconia oxides particles produced at various solvents and drying times. (a) water, $6 \mathrm{~h}$ drying time; (b) water, $12 \mathrm{~h}$ drying time; (c) 70/30 (v/v) water/ethanol, $6 \mathrm{~h}$ drying time; (d) 70/30 (v/v) water/ethanol, $12 \mathrm{~h}$ drying time; (e) $50 / 50(\mathrm{v} / \mathrm{v})$ water/ethanol, $6 \mathrm{~h}$ drying time; (f) $50 / 50(\mathrm{v} / \mathrm{v})$ water/ethanol, $12 \mathrm{~h}$ drying time; (g) 70/30 (v/v) water/ethylene glycol, 6 h drying time; (h) 70/30 (v/v) water/ethylene glycol, $12 \mathrm{~h}$ drying time.

The drying time also influenced the morphology of particles. For water and mixed water/ethylene glycol $(70 / 30(\mathrm{v} / \mathrm{v}))$ as solvent, the longer the drying time, the smaller particles were obtained. In contrast, by addition ethanol into the water, the bigger particles were formed for longer drying time. In water and mixed water/ethylene glycol, the drying process reduced the agglomeration effect on the particles due to slower evaporation. However, for mixed water/ethanol, the property of solvent became more volatile than water itself, and it resulted in fast evaporation of the particles, and agglomeration was still occurred. Vehring et al. [10] explained that longer drying proses resulted in slower evaporation and bigger particle size. Longer drying time, it proposed the agglomeration of particles [11].

Scanning result of EDX analysis for ceria zirconia oxides particles produced with mixed water/ethylene glycol (70/30 (v/v)) and $12 \mathrm{~h}$ drying time is depicted in Figure 2. It was confirmed that produced particles were composed of cerium, zirconium, and oxygen atom. This result also confirmed that composite of ceria zirconia oxides particles were produced. The result was in agreement with the previous work [11] that ceriazirconia oxide composite could be produced in continuous hydrothermal treatment.

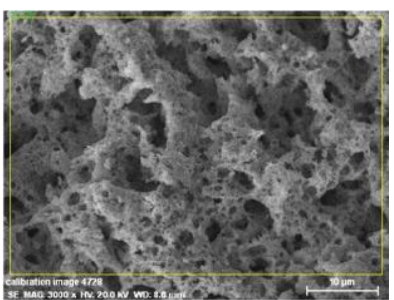

(a)

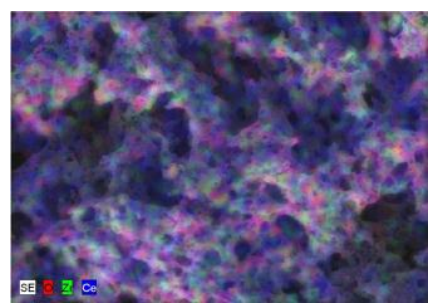

(b)

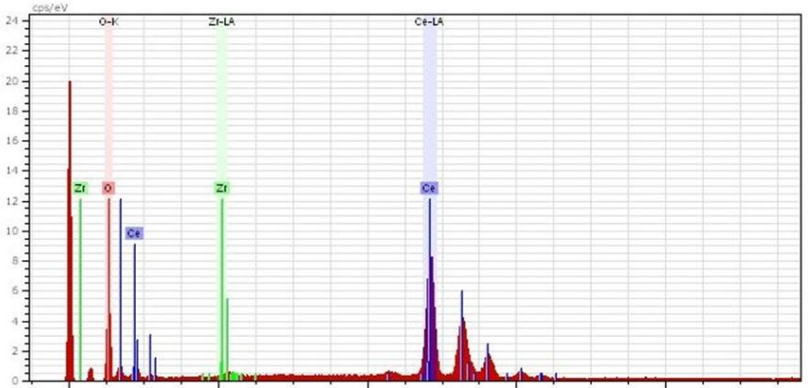

(c)

Fig. 2. EDX analysis of ceria zirconia oxides particles produced with $70 / 30(\mathrm{v} / \mathrm{v})$ water/ethylene glycol solvent and 12 $\mathrm{h}$ drying time.

XRD is a powerful method for the study of nanomaterials, especially to characterize crystallographic structure for bulk, nano and thin film materials. Figure 3 shows XRD pattern of ceria zirconia oxides particles produced with various solvents at $6 \mathrm{~h}$ drying time. All particles produced with all types of solvents showed in crystal form. The addition of organic solvent in the water solvent induced the crystal particles formation. The diffraction lines at $2 \theta=28.25^{\circ}, 34.20^{\circ}, 49.30^{\circ}, 57.52^{\circ}$ and $59.07^{\circ}$ correspond to the composite ceria-zirconia oxides. These figures also indicated that the diffraction patterns of ceria-zirconia oxides particles are uniformly distributed in the structure to form a homogeneous solid solution. Under hydrothermal and solvothermal conditions, an increase in temperature will increase both the nucleation rate and the linear growth rate, hence, the crystallinity of the samples normally increases in time. With the same reaction time, at higher temperature leads to the crystallization of denser products [12]. At the same temperature, the addition of chemicals including organic solvent in the hydrothermal synthesis increased the crystallinity of the particles. Therefore, as shown in Figure 3, the higher volume of ethanol resulted in higher peak intensities while pure water resulted in lower peak intensities. 


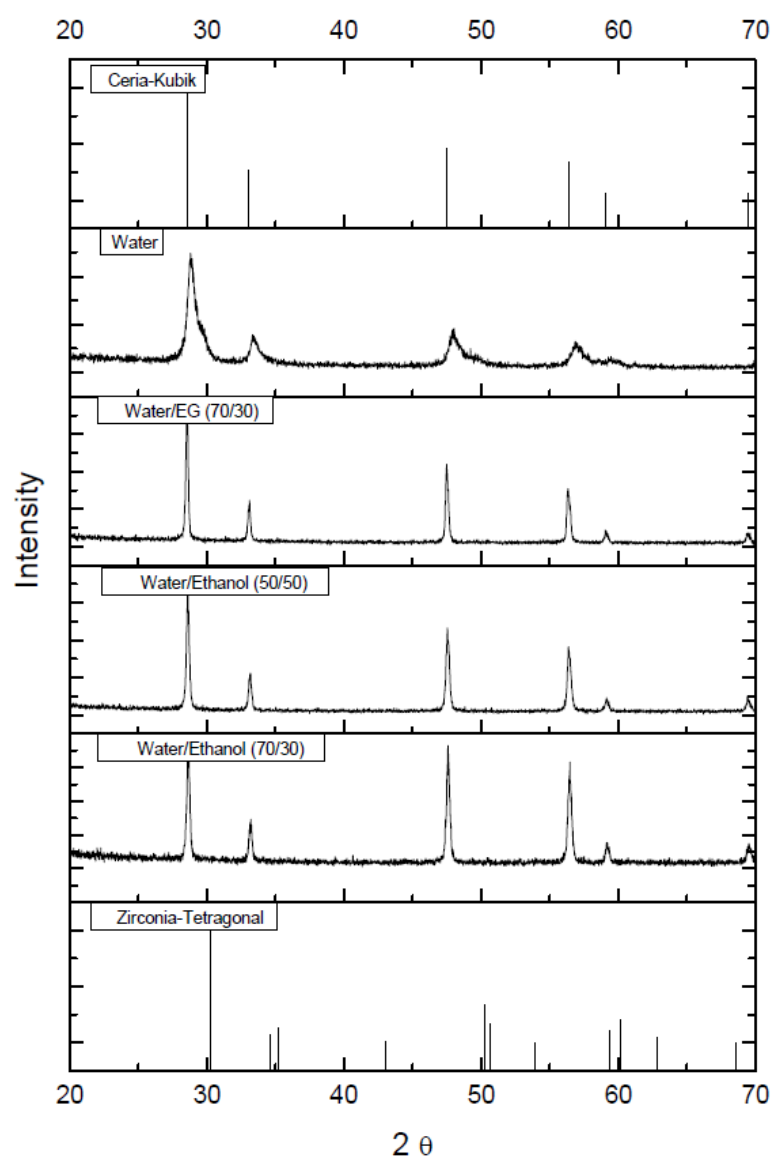

Fig. 3. XRD patterns of ceria zirconia oxides particles produced by various solvents at $6 \mathrm{~h}$ drying time.

Table 1. Total oxygen storage capacity (OSC) of ceria zirconia particles produced by various solvents at $6 \mathrm{~h}$ drying time.

\begin{tabular}{|c|c|c|}
\hline Solvent & $\begin{array}{c}\text { Temperature } \\
\text { Maximum }\left({ }^{\mathbf{0}} \mathbf{C}\right)\end{array}$ & OSC (\%) \\
\hline Water & 410 & 1.82 \\
\hline $\begin{array}{c}\text { Water/Ethanol } \\
(70 / 30)\end{array}$ & 580 & 2.09 \\
\hline $\begin{array}{c}\text { Water/Ethanol } \\
(50 / 50)\end{array}$ & 585 & 51.76 \\
\hline $\begin{array}{c}\text { Water/E. Glycol } \\
(70 / 30)\end{array}$ & 480 & 0.61 \\
\hline
\end{tabular}

Table 1 shows total oxygen storage capacity (OSC) of ceria zirconia oxides particles produced with various solvents and $6 \mathrm{~h}$ drying time. OSC represents the ability of particles to store oxygen to be reacted with hydrogen in SOFC. The addition of ethanol into the solvent increased the stability and OSC of the particles. With the addition of $50 \%$ volume of ethanol into the solvent resulted stability of particles up to $585^{\circ} \mathrm{C}$ with the highest OSC $51.76 \%$. It can be confirmed with the SEM image of particles obtained with water/ethanol (50/50 $(\mathrm{v} / \mathrm{v}))$ that smaller particles were obtained at this condition. The smaller particles caused the larger surface area and larger area to contact with the oxygen atom. In the previous work [13], the supercritical synthesis could lead to ceria-zirconia mixed oxides with higher thermal stability and better OSC. At supercritical synthesis, the operating temperature was much higher than the hydrothermal synthesis, and the process may result in smaller particle size.

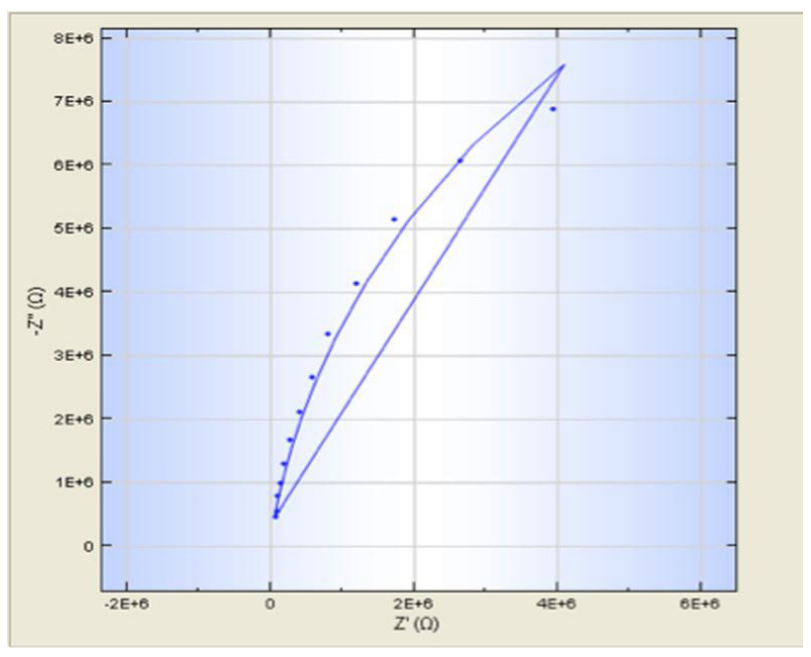

Fig. 4. Nyquist plot of ceria zirconia oxides particles produced by water/ethanol (70/30) at $6 \mathrm{~h}$ drying time.

Figure 4 shows Nyquist plot of ceria zirconia oxides particles produced by water/ethanol (70/30) at $6 \mathrm{~h}$ drying time. The Nyquist plot is a plot of Z' (real value of impedance) versus $-Z$ " (imaginer value of impedance) composed of two curve parts, power part and linear part. The power curve part performs the characteristic of material sample to be measured and the interface resistant of electrode material, while the linear curve part performs the resistant of material sample. Based on the curve, the obtained resistant $|\mathrm{Z}|$ of material sample (ceria zirconia oxides particles) is $0.2669 \Omega$. Furthermore, the conductivity of material sample $(\sigma)$ was calculated using Equation (1):

$$
\sigma=1 / \mathrm{R} \times \mathrm{A}
$$

where $\sigma$ is conductivity $(\mathrm{S} / \mathrm{cm}), 1$ is sample thickness $(\mathrm{cm}), \mathrm{R}$ or $|\mathrm{Z}|$ is sample resistant $(\Omega)$, and A is surface area of sample $\left(\mathrm{cm}^{2}\right)$.

In this work, the impedance measurement was conducted with $0.3 \mathrm{~cm}$ sample thickness and $2.0096 \mathrm{~cm} 2$ surface area of sample. Based on the calculation, conductivity of ceria zirconia oxides particles was $0.5594 \mathrm{~S} / \mathrm{cm}$. This result is higher than the conductivity of zirconia based oxide material reported by $\mathrm{Lv}$ et al. [14]. They reported that zirconia doped with yittria $\left(\mathrm{Y}_{2} \mathrm{O}_{3}\right)$, scandia and ytterbia $\left(\mathrm{Yb}_{2} \mathrm{O}_{3}\right)$ achieved maximum electrical conductivity of $0.18 \mathrm{~S} / \mathrm{cm}$, and zirconia doped with yittria $\left(\mathrm{Y}_{2} \mathrm{O}_{3}\right)$, dysprosia $\left(\mathrm{Dy}_{2} \mathrm{O}_{3}\right)$ and ytterbia $\left(\mathrm{Yb}_{2} \mathrm{O}_{3}\right)$ had maximum electrical conductivity of 0.16 $\mathrm{S} / \mathrm{cm}$. Moreover, ceria zirconia oxides particles produced with water/ethanol $(70 / 30(\mathrm{v} / \mathrm{v}))$ as solvent meets the requirement of SOFC electrolyte. The minimum ion conductivity requirement of SOFC electrolyte is 0.01 $\mathrm{S} / \mathrm{cm}$. 


\section{Conclusion}

Ceria zirconia oxides particles has been prepared using solvothermal synthesis at various solvents. The synthesis was carried out at temperature of $150^{\circ} \mathrm{C}$ for $2 \mathrm{~h}$ in a Teflon-lined autoclave of $100 \mathrm{~mL}$ volume. The synthesis solvents influenced the morphology and size of ceria zirconia oxides particles formed. Ceria zirconia oxides produced via solvothermal synthesis had high conductivity ion of $0.5594 \mathrm{~S} / \mathrm{cm}$, which is higher than minimum conductivity ion requirement of $0.01 \mathrm{~S} / \mathrm{cm}$ for SOFC electrolyte. It indicated that ceria zirconia oxides produced via solvothermal synthesis is suitable for SOFC electrolyte.

\section{Acknowledgement}

This research was supported by a grant from Directorate General of Science, Technology and Higher Education, Ministry of Research, Technology and Higher Education of the Republic of Indonesia through a desentralisasi research grant Penelitian Unggulan Perguruan Tinggi contract no. 616/PKS/ITS/2017.

\section{References}

1. A.B. Stambouli, E. Traversa, Renew. Sustain. Energy Rev. 6, 433 (2002).

2. T. Hibino, H. Tsunekawa, S. Tanimoto, N. Sano, J. Electrochem. Soc. 147, 1338 (1990).

3. Y. Nagai, T. Nonaka, A. Suda, M. Sugiura, R\&D Rev. Toyota CRDL 37, 1-20 (2002).

4. M. Fernandez-Garcia, A. Martinez-Arias, J.C. Hanson, J.A. Rodriguez, Chem. Rev. 104, 4063 (2004)

5. S. Machmudah, O.P. Prastuti, Widiyastuti, S. Winardi, Wahyudiono, H. Kanda, M. Goto, Res. Chem. Intermed. 42, 5367 (2016).

6. V.M. Bekale, C. Legros, C. Haut, G. Sattonnay, A.M. Huntz, Solid State Ion. 177, 3339 (2006).

7. T.R.N. Kutty, J.A.K. Tareen, B. Basavalingu, B. Puttaraju, Mater. Lett. 1, 67 (1982).

8. S. Komarneni, D. Li, B. Newalkar, H. Katsuki, A.S. Bhalla, Langmuir 18, 5959 (2002).

9. K. Kanie, Y. Seino, M. Matsubara, M. Nakaya, A. Muramatsu, New J. Chem. 38, 3548 (2014).

10. R. Vehring, W.R. Foss, D. Lechuga-Ballesteros, J. Aeros. Sci. 38, 728 (2007).

11. J.-R. Kim, K.-Y. Lee, M.-J. Suh, S.-K. Ihm, Cat. Today 185, 25 (2012).

12. S. Machmudah, M.A. Hadian, L. Samodro, S. Winardi, Wahyudiono, H. Kanda, M. Goto, Modern Appl. Sci. 9, 134 (2015).

13. J.-R. Kim, W.-J. Myeong, S.-K. Ihm, Appl. Cat. B: Environ. 71, 57 (2007).

14. Z.G. Lv, P. Yao, R.S. Guo, F.Y. Dai, Mat. Sci. Eng. A 458, 355 (2007). 